\title{
AUDEN, MAGNEIGE, SPENDER: THE THIRTIES POETRY
}


By the same authors

\section{MICHAEL O'NEILL}

\section{Literary Criticism}

The Human Mind's Imaginings: Conflict and Achievement in Shelley's Poetry

Percy Bysshe Shelley: A Literary Life

Poetry

The Stripped Bed

GARETH REEVES

Literary Criticism

T. S. Eliot: A Virgilian Poet

Selected Poems of George Herbert (ed.)

\section{Poetry}

Real Stories 


\section{AUDEN, MACNEICE, SPENDER: THE THIRTIES POETRY}

Michael O'Neill and Gareth Reeves

Macmillan Education 
ISBN 978-0-333-45118-2 ISBN 978-1-349-21904-9 (eBook)

DOI 10.1007/978-1-349-21904-9

(C) Michael O'Neill and Gareth Reeves 1992

Softcover reprint of the hardcover 1st edition 1992

All rights reserved. For information, write:

Scholarly and Reference Division,

St. Martin's Press, Inc., 175 Fifth Avenue,

New York, N.Y. 10010

First published in the United States of America in 1992

ISBN 978-0-312-06828-8

Library of Congress Cataloging-in-Publication Data

O'Neill, Michael, 1953-

Auden, MacNeice, Spender : the thirties poetry / Michael O'Neill and Gareth Reeves.

p. $\mathrm{cm}$.

Includes bibliographical references and index.

ISBN 978-0-312-06828-8

1. English poetry-20th century-History and criticism. 2. Auden, W. H. (Wystan Hugh), 1907-1973-Criticism and interpretation.

3. MacNeice, Louis, 1907-1963-Criticism and interpretation.

4. Spender, Stephen, 1909- - Criticism and interpretation. 5. e -uk. I. Reeves, Gareth, 1947- . II. Title.

PR610.054 1992

$821 ' .91209-\mathrm{dc} 20$

91-28970

CIP 


\section{Contents}

Acknowledgements

Note on Texts and Abbreviations

vi

Introduction

viii

1 Auden (1)

'An altering speech' 6

2 Spender (1)

'The sense of falling light'

3 MacNeice (1)

Turning the Music On

63

4 Auden (2)

The Orators: 'They stole to force a hearing' 85

5 Spender (2)

'To will this Time's change' 116

6 Auden (3)

'A change of heart'

7 MacNeice (2)

Autumn Journal: 'A monologue is the death of language' 181

8 Poetry of the Spanish Civil War

'See Spain and see the world'

Notes

243

Index 


\section{Acknowledgements}

We are grateful to the University of Durham for granting us terms of Research Leave during which we have been able to work on and finish this book, and to the staff of the University Library for all their help. We owe a special debt to students who took our Special Topic course on Poetry of the 1930s; the book has its origins in the teaching of that course.

Excerpt from The English Auden: Poems, Essays and Dramatic Writings 1927-1939 edited by Edward Mendelson, and The Orators by W. H. Auden, are reprinted by permission of Faber and Faber, Ltd. Excerpts from W. H. Auden: Collected Poems by W. H. Auden, copyright (C) 1934, 1937, 1940, 1945 by W. H. Auden and renewed 1962, 1965, 1968 by W. H. Auden, are reprinted by permission of Random House, Inc. Excerpts from Poems (1933; 2nd edn 1934), The Still Centre, Collected Poems 1928-1953, and Collected Poems $1928-1985$ by Stephen Spender, copyright (C) 1934, 1942 by Stephen Spender, renewed 1962 by Stephen Spender, are reprinted by permission of Random House, Inc., and Faber and Faber, Ltd. Excerpts from The Collected Poems of Louis MacNeice edited by E. R. Dodds are reprinted by permission of Faber and Faber, Ltd. The excerpts from 'Preludes' in Collected Poems 1909-1962 by T.S. Eliot, copyright 1936 by Harcourt Brace Jovanovich, Inc., copyright (C) 1964, 1963 by T. S. Eliot, is reprinted by permission of Harcourt Brace Jovanovich, Inc., and Faber and Faber, Ltd. The excerpt from 'From the Canton of Expectation' in The Haw Lantern by Seamus Heaney, copyright (C) 1987 by Seamus Heaney, is reprinted by permission of Farrar, Straus and Giroux, Inc., and Faber and Faber, Ltd. Excerpts from The Poems of Laura 
Riding: A New Edition of the 1938 Collection are reprinted by kind permission of Laura (Riding) Jackson and Carcanet Press, Ltd.

The book is very much a joint venture. However, Michael O'Neill is primarily responsible for Chapters 2, 5, 6 (except the final section) and 8; Gareth Reeves is primarily responsible for Chapters 1, 3, 4, 7 and the final section of 6 (on In Time of War). 


\section{Note on Texts and Abbreviations}

Except where indicated otherwise, all quotations from Auden's poetry are taken from The English Auden: Poems, Essays and Dramatic Writings 1927-1939, ed. Edward Mendelson (London, 1977). This work is hereafter referred to as $E A$. Auden's poems are referred to by first line or title, as in $E A$.

Except where indicated otherwise, all quotations from MacNeice's poetry are taken from The Collected Poems of Louis MacNeice, ed. E. R. Dodds (1966; rpt London and Boston, 1979). This work is hereafter referred to as CPM.

Except where indicated otherwise, all quotations from Spender's poetry are taken from the collections he published in the 1930s. See the opening section of Chapter 2 for fuller details.

Other abbreviations used in the book:

Casebook Thirties Poets: 'The Auden Group', A Casebook, ed. Ronald Carter (London and Basingstoke, 1984).

CPS(1) Stephen Spender, Collected Poems 1928-1953 (London, 1955).

CPS(2) Stephen Spender, Collected Poems 1928-1985 (London and Boston, 1985).

CSPA W. H. Auden, Collected Shorter Poems 19271957 (1966; rpt London, 1969). 
Cunningham Valentine Cunningham, British Writers of the Thirties (Oxford and New York, 1988).

$D E$

Stephen Spender, The Destructive Element: A Study of Modern Writers and Beliefs (London, 1935).

Everett Barbara Everett, Auden (Edinburgh and London, 1964).

Fantasia D. H. Lawrence, Fantasia of the Unconscious (1923; rpt London, 1933).

Fuller

John Fuller, A Reader's Guide to W.H. Auden (London, 1970).

Hynes

Samuel Hynes, The Auden Generation: Literature and Politics in England in the 1930s (London and Boston, 1976).

Longley Edna Longley, Poetry in the Wars (Newcastle upon Tyne, 1986).

$\mathrm{Mac}$

Edna Longley, Louis MacNeice: A Study (London and Boston, 1988).

Mendelson Edward Mendelson, Early Auden (London and Boston, 1981).

PBSCWV The Penguin Book of Spanish Civil War Verse, ed. Valentine Cunningham (1980; rpt Harmondsworth, 1983).

PFS Poems for Spain, eds Stephen Spender and John Lehmann (London, 1939).

SAF Louis MacNeice, The Strings Are False: An Unfinished Autobiography (1965; rpt London and Boston, 1982).

$S C \quad$ Stephen Spender, The Still Centre (London, 1939).

SCM Selected Literary Criticism of Louis MacNeice, ed. Alan Heuser (Oxford, 1987).

Smith Stan Smith, W.H. Auden (Oxford and New York, 1985).

SPS Stephen Spender, Selected Poems (London and Boston, 1965).

SP33 Stephen Spender, Poems (London, 1933).

SP34 Stephen Spender, Poems 2nd edn (London, 1934).

$T$

Stephen Spender, The Temple 2nd edn (London and Boston, 1989). 
The Thirties and After

WHACP

$W W W$
Stephen Spender, The Thirties and After: Poetry, Politics, People 1933-75 (Glasgow, 1978).

W. H. Auden, Collected Poems, ed. Edward Mendelson (London, 1976).

Stephen Spender, World Within World (1951; rpt London, 1977). 